ISSN 1392-3196 / e-ISSN 2335-8947

Zemdirbyste-Agriculture, vol. 108, No. 2 (2021), p. 117-124

DOI 10.13080/z-a.2021.108.015

\title{
Impacts of itaconic acid on the physiological traits of crop seedlings
}

\author{
Yaling $\mathrm{LU}^{1,2}$, Xuewen $\mathrm{LI}^{2}$, Wan WANG ${ }^{2}$, Shunnian $\mathrm{LI}^{2}$, Yafei $Z \mathrm{ZHANG}^{2}$, Liuyang XUAN ${ }^{2}$, \\ Pingfang TIAN ${ }^{1}$ \\ ${ }^{1}$ Beijing University of Chemical Technology, College of Life Science and Technology \\ Beijing 100029, China \\ E-mail: tianpf@mail.buct.edu.cn \\ ${ }^{2}$ Tarim University, Xinjiang Production and Construction Corps Key Laboratory of Protection and \\ Utilization of Biological Resources in Tarim Basin \\ Alar 843300, China
}

\begin{abstract}
Itaconic acid (IA) is an economically important platform chemical, which finds wide applications in chemical industry and agriculture. This study attempted to ascertain the influence of IA on crop seedlings. Four crops including maize, cucumber, sorghum and wheat were grown in hydroponics containing Hoagland's nutrient solution and one of serially diluted IA. The biomass, the activities of antioxidant enzymes and the content of chlorophyll and malondialdehyde (MDA) in seedlings were investigated. Results showed that low concentration of IA ( $\left.\leq 200 \mathrm{mg} \mathrm{L}^{-1}\right)$ benefited crop growth and alleviated oxidative stress, as it not only improved biomass, leaf area, chlorophyll content, the activities of catalase (CAT) and peroxidase (POD), but also reduced the formation of MDA and the activities of ascorbate peroxidase (APX) and superoxide dismutase (SOD). IA exerted different physiological and antioxidant influences on crops. The physiological impacts of IA on crops in descending order are cucumber $>$ wheat $>$ maize $>$ sorghum. Overall, IA stimulated crop growth through affecting biochemical components such as antioxidant enzymes and chlorophyll. This study provides the basis for future use of IA as a fertilizer.
\end{abstract}

Key words: itaconic acid, crop seedlings, antioxidant enzymes, physiological impacts.

\section{Introduction}

Itaconic acid (IA) is one of 12 top-valued renewable chemicals proposed by the United States Department of Energy (Werpy, Petersen, 2004). The market volume of IA is estimated to be USD 102.3 million by 2022 (https://www.marketsandmarkets.com/ Market-Reports/itaconic-acid-market-35695455.html). To date, IA has been widely used for manufacturing biodegradable polymers such as synthetic latex, antifreeze, superabsorbent polymers and unsaturated polyester resin (Qi et al., 2016; Robert, Friebel, 2016; Müller et al., 2018). Some of IA-based polymers serve as water-retaining agent and fertilizer release coating (Takić Miladinov et al., 2016; Urbano-Juan et al., 2019). In recent years, impressive progress has been made in understanding of the versatility of IA (Meiser et al., 2018). For instance, IA has functions of anti-inflammation (Cordes et al., 2015), antioxidation, antibacterial (Patel, McFadden, 1978; Hillier, Charnetzky, 1981), antivirus and modulation of nutrition metabolism (Ryan et al., 2019). As a renewable chemical, IA is a promising alternative to other chemicals
(Magalhaes et al., 2016; Ramos et al., 2016; Zhao et al., 2018).

Crop growth relies on both inorganic and organic elements. Low-molecular-weight organic acids are ubiquitous in nature and substantially affect the survival of crops. Although organic acids are of paramount importance for the growth and development of crops, their primary function may be assistance of the release of soil nutritive substances, which in turn ameliorate crop viability. Organic acids assist in the release of nutrient elements by means of reduction, ion exchange, complexation, chelation or acid dissolution (Adeleke et al., 2017). Although IA is an important organic acid, it has not been widely applied in agriculture so far (Sanders, 2010; Chien et al., 2014; Forrestal et al., 2016 ), and little is known about its real-world performance as a fertilizer. In this study, four crops including maize, cucumber, sorghum and wheat were investigated for their responses to IA. Upon exposure to IA: 50, 80, 100, 200 and $300 \mathrm{mg} \mathrm{L}^{-1}$, the crops were grown in hydroponics

Please use the following format when citing the article:

Lu Y., Li X., Wang W., Li S., Zhang Y., Xuan L., Tian P. 2021. Impacts of itaconic acid on the physiological traits of crop seedlings. Zemdirbyste-Agriculture, 108 (2): 117-124. DOI 10.13080/z-a.2021.108.015 
till four-leaf stage. The leaf area, stem height, biomass weight, chlorophyll content, antioxidant activities and malondialdehyde content were immediately examined after harvest. To our knowledge, this is the first systematic assessment of how IA regulates the growth of investigated crops. Overall, this study aims to fully assess IA as a novel fertilizer.

\section{Materials and methods}

Crop growth and treatment. Crop growth experiment was conducted in Xinjiang Production and Construction Corps Key Laboratory of Protection and Utilization of Biological Resources in Tarim Basin, China from 2017 to 2018. In view of pre-experiments, four crops: maize, cucumber, sorghum and wheat, were chosen for the present study. These crops were grown in hydroponics in pots containing vermiculite, and Hoagland's solution was used to irrigate the crops every 3 days. The pots were placed in the Tissue Culture Laboratory of Key Laboratory at $24 \pm 2^{\circ} \mathrm{C}$ temperature with a $12 \mathrm{~h}$ photoperiod, $30 \pm 3 \%$ relative humidity and irradiation of $90 \mu \mathrm{mol} \mathrm{m} \mathrm{m}^{-2} \mathrm{~s}^{-1}$. Seeds of maize, cucumber, sorghum and wheat were kindly provided by Liaoning Dongya Agricultural Development Co. Ltd., Urumqi Evergreen Garden Seed Co. Ltd., Taigu Dazhi Seed Industry Co. Ltd. and Xinjiang Shengyuan Seed Industry Co. Ltd., respectively. Seeds of similar weight and size were immersed in $2 \%$ hypochlorite solution for 5 10 min, then rinsed three times with distilled water and lastly soaked in distilled water for $24 \mathrm{~h}$. The vermiculite was thoroughly wetted with distilled water and incubated for $24 \mathrm{~h}$ prior to planting. Next, these seeds were sown in pots $(11 \times 10 \mathrm{~cm}, 5$ seeds per pot and total 30 pots per crop) and placed on the shelf of the Tissue Culture Laboratory. The seeds were cultivated twice a year. Seeds were equidistantly positioned in vermiculite at a depth of $1 \mathrm{~cm}$ and irrigated by one of serial concentrations $(50$, 80, 100, 200 and $300 \mathrm{mg} \mathrm{L}^{-1}$ ) of itaconic acid (IA). For the control, vermiculite was irrigated with distilled water. After the same-sized sprouts were available, the pots were irrigated with $150 \mathrm{~mL}$ distilled water (every 5 days) and $100 \mathrm{~mL}$ IA (every 3 days).

Crop harvest and agronomic parameters. After these crops accomplished seedling growth (manifesting fully developed four-leaves), they were harvested, rinsed with distilled water and subsequently partitioned into roots, stems and leaves. The leaf area, stem height and fresh tissue weight were immediately measured. The last two fully developed fresh leaves were collected to examine not only the contents of chlorophyll (chl) and malondialdehyde (MDA) but also the antioxidant responses of enzymes ascorbate peroxidase (APX), catalase (CAT), superoxide dismutase (SOD) and peroxidase (POD).

Contents of chlorophyll (chl) and carotenoids. The contents of total chl, $\operatorname{chl} a, \operatorname{chl} b$ and carotenoids were examined using a $2400 \mathrm{UV}$-visible spectrophotometer (Shunyu, China). Briefly, $0.5 \mathrm{~g}$ fresh leaves were ground with a mortar and $80 \%$ acetone (v/v). The detection wavelengths for chl $a$, chl $b$ and carotenoids were 466 , 645 and $663 \mathrm{~nm}$, respectively. The content of chlorophyll was calculated using Arnon (1949) formula with minor modifications. The content of chlorophyll or carotenoids was described as the milligrams per gram $\left(\mathrm{mg} \mathrm{g}^{-1}\right)$ of fresh weight (FW).

Antioxidant enzyme assay. Enzymes were extracted according to Beyer and Fridovich (1987) with minor modifications. Briefly, $0.25 \mathrm{~g}$ of fresh leaves were smashed, immersed into a mixture containing pre-cooled $5 \mathrm{~mL}$ of $50 \mathrm{mmol} \mathrm{L}^{-1}$ phosphate buffer at $\mathrm{pH} 7.8$ and $1 \%$ polyvinylpyrrolidone and then homogenized under icecold conditions. The homogenates were centrifuged at $10,000 \mathrm{rpm}$ and $4^{\circ} \mathrm{C}$ for $10 \mathrm{~min}$. The resulting supernatant was stored at $-20^{\circ} \mathrm{C}$ temperature and subsequently subjected to analysis of antioxidant enzymes.

Ascorbate peroxidase (APX) assay. A portion of $0.2 \mathrm{~mL}$ of enzyme extract was added into $3 \mathrm{~mL}$ reaction mixture containing $50 \mathrm{mmol} \mathrm{L} \mathrm{L}^{-1}$ phosphate buffer $(\mathrm{pH}$ 7.0), $0.1 \mathrm{mmol} \mathrm{L}^{-1}$ EDTA Na, $0.5 \mathrm{mmol} \mathrm{L}^{-1}$ ascorbic acid and $0.1 \mathrm{mmol} \mathrm{L}^{-1} \mathrm{H}_{2} \mathrm{O}_{2}$ (hydrogen peroxide). The reaction system without ascorbic acid and $\mathrm{H}_{2} \mathrm{O}_{2}$ was used as the control. At room temperature, the absorbance at $290 \mathrm{~nm}$ was recorded per $10 \mathrm{~s}$ till $1 \mathrm{~min}$ to determine APX (Nakano, Asada, 1981). One unit of APX is defined as 1 $\mu \mathrm{mol}$ ascorbate oxidized per minute per gram.

Superoxide dismutase (SOD) assay. The SOD activity was determined using nitro-blue tetrazolium (NBT) method (Beauchamp, Fridovich, 1971) with minor modifications. Briefly, a mixture containing $50 \mathrm{mmol} \mathrm{L}^{-1}$ phosphate buffer ( $\mathrm{pH} 7.8$ ), $13 \mathrm{mmol} \mathrm{L}^{-1}$ methionine solution, $75 \mu \mathrm{mol} \mathrm{L}{ }^{-1} \mathrm{NBT}, 10 \mu \mathrm{mol} \mathrm{L}-1$ EDTA Na, $0.4 \mathrm{~mL}$ enzyme extract and $0.5 \mathrm{~mL}$ of $20 \mu \mathrm{mol} \mathrm{L}^{-1}$ riboflavin solution was prepared. The detection wavelength was $560 \mathrm{~nm}$. The mixture devoid of enzyme extract was used as the control. One unit of SOD is defined as the amount of enzyme that inhibits photoreduction of $50 \%$ NBT per gram.

Catalase (CAT) assay. The CAT activity was investigated using UV absorption method (Goldblith, Proctor, 1950; Beers, Sizer, 1952). Briefly, a total of $3 \mathrm{~mL}$ assay mixture containing $50 \mathrm{mmol} \mathrm{L}^{-1}$ phosphate solution ( $\mathrm{pH} 7.0), 0.2 \mathrm{~mL}$ of enzyme extract and $0.02 \% \mathrm{H}_{2} \mathrm{O}_{2}$ was prepared. The absorbance at $240 \mathrm{~nm}$ was recorded per minute till $5 \mathrm{~min}$. One unit of CAT is defined as $1 \mu \mathrm{mol}$ $\mathrm{H}_{2} \mathrm{O}_{2}$ consumed per minute per gram.

Peroxidase (POD) assay. The POD activity was determined using the guaiacol method (Amako et al., 1994). Briefly, $3 \mathrm{~mL}$ assay mixture containing $50 \mathrm{mmol} \mathrm{L}^{-1}$ phosphate buffer ( $\mathrm{pH} 6.0), 0.06 \%(\mathrm{v} / \mathrm{v})$ guaiacol and $0.1 \%$ $\mathrm{H}_{2} \mathrm{O}_{2}$ was prepared. A total of $0.2 \mathrm{~mL}$ of enzyme extract was required for experiments. The change in absorbance at $470 \mathrm{~nm}$ per minute was recorded for $4 \mathrm{~min}$. One unit of POD was calculated with 0.01 increase in optical density (OD) per minute per gram.

Malondialdehyde (MDA) assay. MDA content reflects the oxidative damage to leaf cells based on lipid peroxidation (Schmedes, Hølmer, 1989). A total weight of $0.5 \mathrm{~g}$ of fresh biomass was cut accurately and ground into pulp in an ice bath containing $5 \mathrm{~mL} 10 \%$ trichloroacetic acid and approximately $0.1 \mathrm{~g}$ quartz sand. The homogenate was centrifuged at $10,000 \mathrm{rpm}$ and $4^{\circ} \mathrm{C}$ temperature for $15 \mathrm{~min}$. Next, $2 \mathrm{~mL}$ supernatant was mixed with $2 \mathrm{~mL} 0.5 \%$ thiobarbituric acid. Afterwards, the test tube containing the mixture was immersed into boiling water for $30 \mathrm{~min}$ and subsequently cooled in an ice bath to terminate the reaction. The reaction mixture was centrifuged at 8,000 rpm for $10 \mathrm{~min}$. The supernatant was subjected to analysis of the absorbance at wavelengths of 450, 532 and $600 \mathrm{~nm}$.

Statistical analysis. One-way analysis of variance (ANOVA) was performed using software SPSS, version 22.0 (IBM Corp., USA). The data presented correspond to mean values and standard error $( \pm S E)$ with five replications for each. Differences among treatments were compared using least significance difference (LSD), and $p \leq 0.05$ was considered as statistically significant. Different letters (a, b, c and d) denote statistically significant differences between IA treatments $(p \leq 0.05)$. 


\section{Results and discussion}

Effect of itaconic acid (IA) on crop growth. Four crops: maize, cucumber, sorghum and wheat, were harvested and investigated for their leaf size and stem height. Results showed that the leaf area varied across crops during seedling stage (Figure 1). Only large-leaved crops were substantially affected by IA treatment at four-leaf stage. For instance, IA treatment only slightly promoted the leaf growth of sorghum and wheat. This may be explained by the fact that sorghum and wheat are small-leaved crops compared with cucumber.

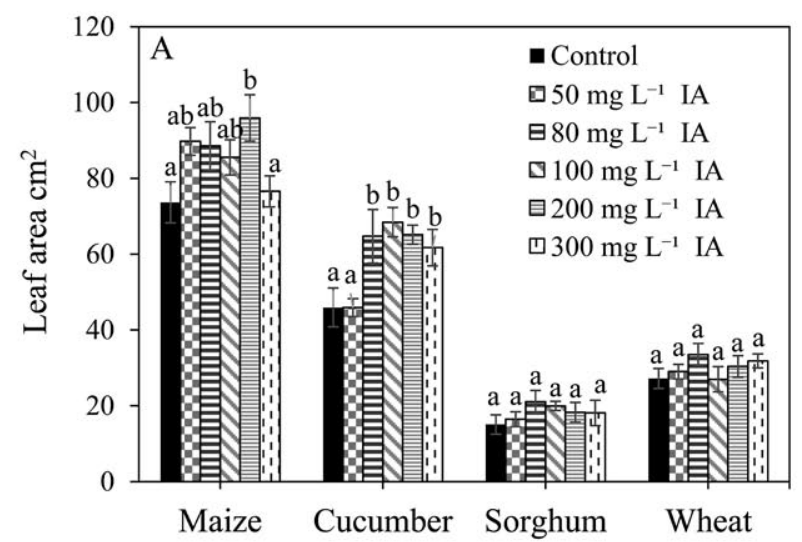

In contrast, $200 \mathrm{mg} \mathrm{L}^{-1}$ IA treatment significantly stimulated the leaf growth of maize and cucumber $(p \leq$ $0.05)$, as they are large-leaved crops relative to wheat and sorghum. It can be deduced from Figure 1 that $200 \mathrm{mg}$ $\mathrm{L}^{-1}$ IA led to $30.26 \%$ increase in leaf area of maize ( $p \leq$ 0.05 ), and $80 \sim 300 \mathrm{mg} \mathrm{L}^{-1}$ IA resulted in $40 \%$ increase in the leaf area of cucumber compared with the control treatment. Clearly, IA exerted higher impacts on largeleaved crops relative to small-leaved crops at four-leaf stage. Apart from above findings, IA did not markedly affect stem height.

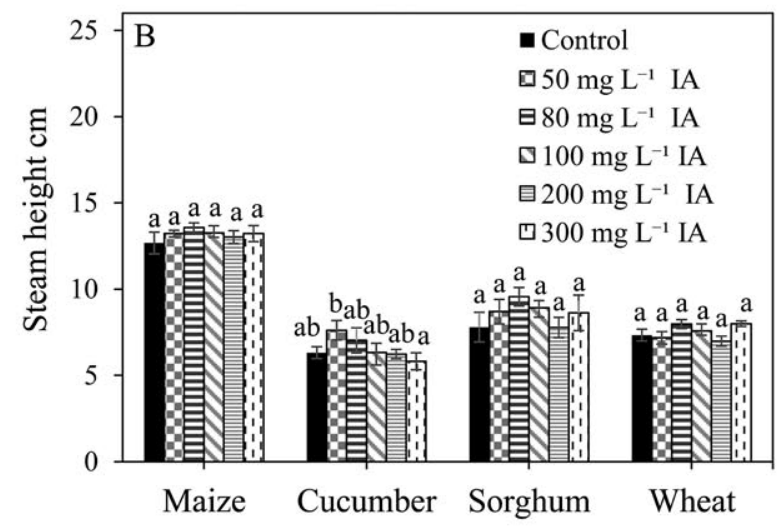

Note. Different letters denote statistically significant differences at $p \leq 0.05$.

Figure 1. Response of leaf area (A) and stem height (B) of investigated crops to itaconic acid (IA) treatment

Effect of IA on biomass of crop tissues. After crops were harvested, the fresh biomass of roots, stems and leaves was immediately measured, and the total biomass, stem to leaf and root to shoot ratios were also calculated. As shown in Figure 2, IA markedly promoted the growth of maize leaves, the roots and leaves of cucumber and the stems and roots of sorghum. For maize, $50 \mathrm{mg} \mathrm{L}^{-1}$ IA significantly improved the growth of leaves and the amount of total biomass. However, high concentration of IA did not significantly promote leaf growth. Upon $300 \mathrm{mg} \mathrm{L}^{-1} \mathrm{IA}$ treatment, the stem to leaf ratio was increased.

Similar phenomenon was also found for IAtreated cucumber. For instance, $80 \sim 300 \mathrm{mg} \mathrm{L}^{-1}$ IA significantly increased the biomass of roots and leaves. However, as shown in Figure 2, IA decreased stem to leaf ratio but increased root to shoot ratio indicating that low concentration of IA might benefit the growth of leaves and stems of cucumber. Regarding sorghum, 80, 100 and $200 \mathrm{mg} \mathrm{L}^{-1}$ IA substantially promoted the growth of roots and stems. However, no significant change was observed in stem height (Figure 1). As for wheat, although IA did not significantly affect the growth of roots, stems and leaves, the stem to leaf and root to shoot ratios were significantly decreased $(p \leq 0.05)$ indicating that IA promotes leaf growth of wheat. To sum up, IA significantly boosted the growth of maize leaves, the roots and leaves of cucumber and the stems and roots of sorghum. Furthermore, IA exerted different levels of physiological impacts on aforementioned crops. As shown in Figure 2, low concentration of IA promoted crop growth, whilst high concentration of IA did not. Clearly, there exists a threshold of IA concentration and above at which crop growth is halted. In addition, IA concentration varies for different crops.

Chlorophyll (chl) and carotenoids contents in leaves. Chlorophyll is the main pigment in photosynthesis
(González et al., 2017), and the total chl includes chl $a$ and $\operatorname{chl} b$. Figure 3 shows the contents of $\operatorname{chl} a, \operatorname{chl} b$, total chl and carotenoids as well as the $\operatorname{chl} a$ to $\operatorname{chl} b$ ratio. It has been reported that the reduction in chlorophyll content due to damage can be alleviated by exogenous applications of organic acids (El-Hmahmy et al., 2017; Zheng et al., 2018). In the present study, no significant differences were observed among IA and control treatments in the contents of chl $a$, chl $b$ and total chl. Upon treatment by $100 \mathrm{mg} \mathrm{L}^{-1} \mathrm{IA}$, the carotenoids content $(0.34 \pm 0.01$ $\left.\mathrm{mg} \mathrm{g}^{-1}\right)$ in sorghum was increased by $25.93 \%(p \leq 0.05)$. These results suggested that IA may benefit chlorophyll formation and in turn facilitate photosynthesis.

Antioxidant traits. It is well known that oxygeninvolved metabolisms often generate reactive oxygen species (ROS). Although ROS participates in signal transduction, it is toxic to crops. To cope with oxidative stress, crops have evolved a set of detoxification mechanisms, which can be roughly divided into two strategies: avoidance and removal. The former involves anatomical, physiological and molecular mechanisms, while the latter involves an enzymatic scavenging system consisting of APX, CAT, SOD and POD (Racchi, 2013; Huang et al., 2015).

Ascorbate peroxidase (APX) activity. Hydrogen peroxide $\left(\mathrm{H}_{2} \mathrm{O}_{2}\right)$ takes part in photosynthetic electron transfer and some enzymatic reactions in chloroplasts. High concentration of $\mathrm{H}_{2} \mathrm{O}_{2}$ inhibits the activities of enzymes in Calvin cycle (Marri et al., 2014). APX not only scavenges the $\mathrm{H}_{2} \mathrm{O}_{2}$ in chloroplast but also governs ascorbic acid metabolism. As one of the key antioxidant enzymes to eliminate active oxygen, APX participates in the ascorbic acid glutathione cycle in crops. Figure 4A displays the APX activity of the crops upon IA treatment.

Results showed that increasing IA concentration inhibited the APX activity of cucumber and wheat. However, no dramatic difference was observed in the 

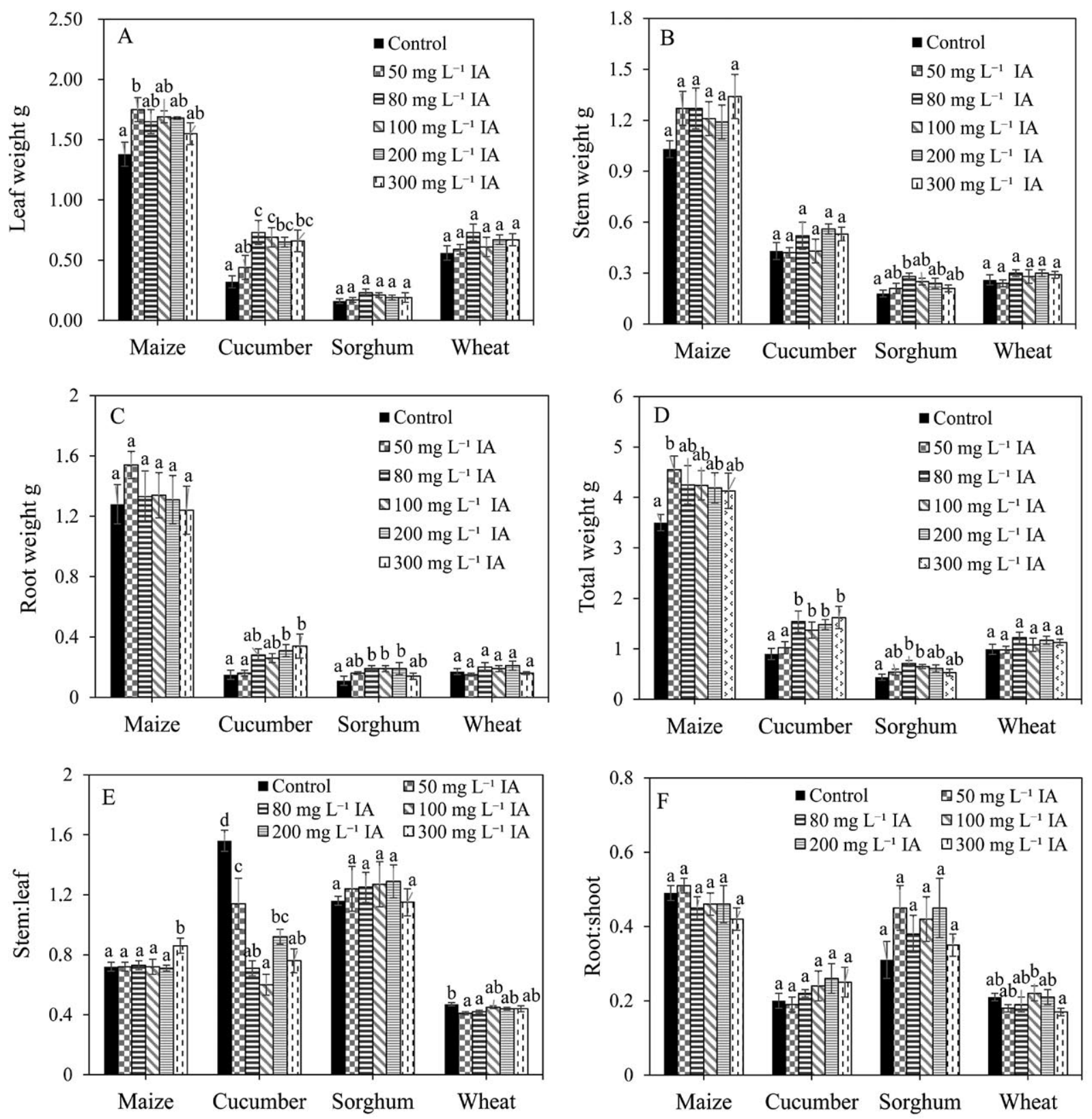

Note. Different letters denote statistically significant differences at $p \leq 0.05$.

Figure 2. Response of fresh biomass of leaf weight (A), stem weight (B), root weight (C) and total weight (D), stem to leaf $(\mathrm{E})$ and root to shoot $(\mathrm{F})$ ratios of investigated crops to itaconic acid (IA) treatment

APX activity of IA-treated maize and sorghum. APX activity in cucumber and wheat was decreased upon 80, 100, 200 and $300 \mathrm{mg} \mathrm{L}^{-1}$ IA treatment compared with the control. Considering APX activity relies mainly on the amount of $\mathrm{H}_{2} \mathrm{O}_{2}$ in seedlings of crop, low APX activity of maize and sorghum might be attributed to the limited $\mathrm{H}_{2} \mathrm{O}_{2}$ in chloroplast. In fact, appropriate amount of $\mathrm{H}_{2} \mathrm{O}_{2}$ is critical for the maintenance of APX activity, and low concentration of IA may attenuate $\mathrm{H}_{2} \mathrm{O}_{2}$, which in turn repress the APX activity of cucumber and wheat.

Superoxide dismutase (SOD) activity. SOD is an active and primary antioxidant enzyme that converts harmful superoxide free radicals into $\mathrm{O}_{2}$ and $\mathrm{H}_{2} \mathrm{O}_{2}$ through disproportionation reaction. SOD is a key enzyme for maintaining normal physiological conditions and coping with oxidative damage caused by ROS (Mittler, 2002). The SOD content is associated with health and senescence, and SOD activity relies on the concentration of $\mathrm{O}_{2}^{-}$. When exposed to harsh environments such as cadmium toxicity, SOD exhibits higher activity relative to the control (Shahabivand et al., 2016). Although $\mathrm{H}_{2} \mathrm{O}_{2}$ is toxic to cells, it can be converted to $\mathrm{H}_{2} \mathrm{O}$ by enzymes CAT and POD, these three enzymes SOD, CAT and POD constitute an antioxidant chain.

In the present study, Figure 4B describes the SOD activity of investigated crops. For cucumber and wheat, IA treatment significantly reduced the SOD activity $(p \leq$ 0.05 ). However, no significant change was observed in the SOD activity of maize and sorghum upon exposure to serial concentrations of IA. This might be attributed to the rapid development and stable APX activity of maize and sorghum. For cucumber and wheat, 80, 100, 200 and $300 \mathrm{mg} \mathrm{L}^{-1}$ IA treatments significantly reduced the activity of SOD indicating that IA attenuated the contents of $\mathrm{O}_{2}^{-}$and $\mathrm{H}_{2} \mathrm{O}_{2}$ and thus retarded ROS generation. The application of IA in cucumber and wheat, which may be 

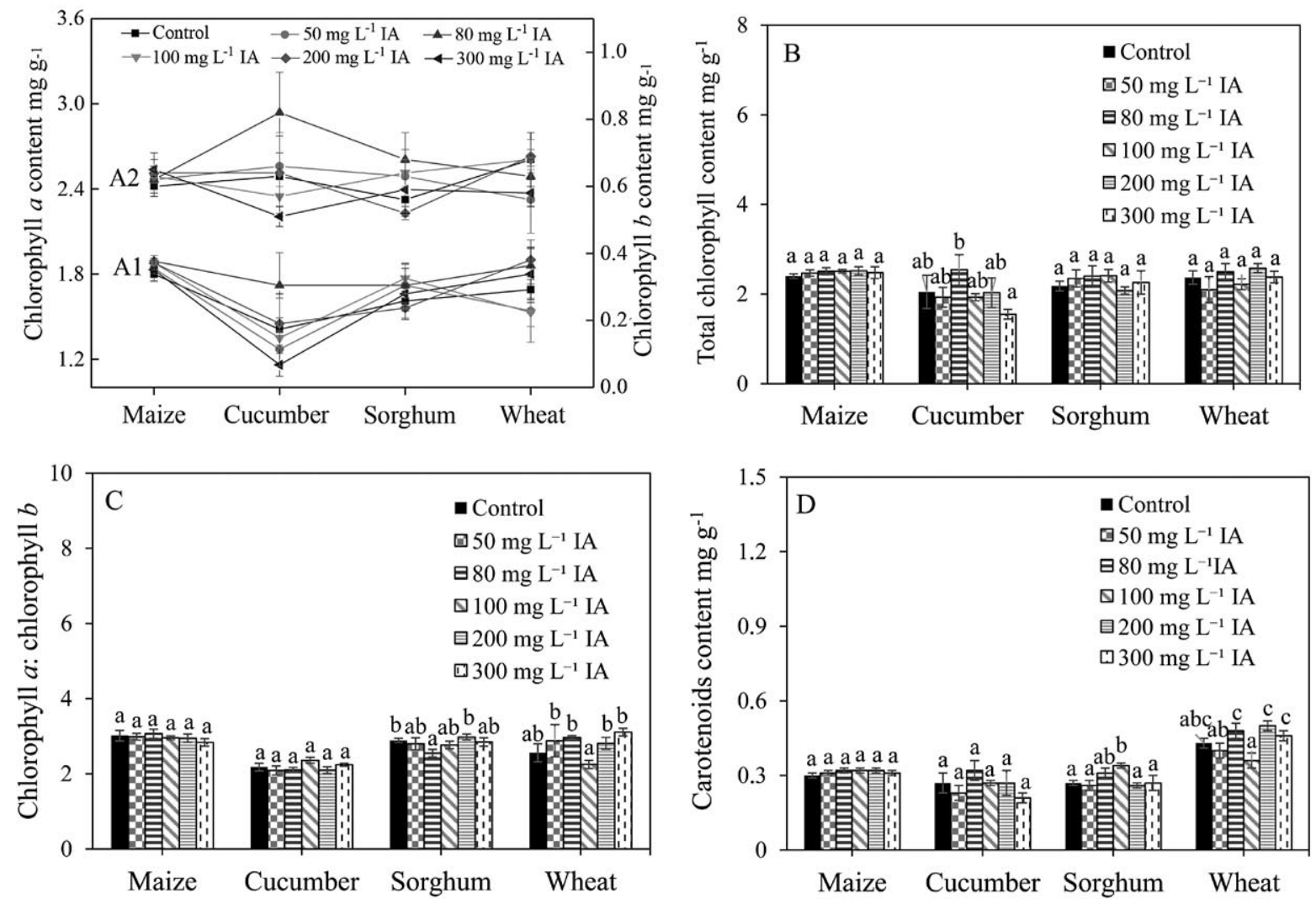

Note. Different letters denote statistically significant differences at $p \leq 0.05$.

Figure 3. Response of chlorophyll content including chl $a$ (A1), chl $b$ (A2), total chl (B), chl $a$ to $\operatorname{chl} b$ ratio (C) and carotenoids content (D) in investigated crops to itaconic acid (IA) treatment
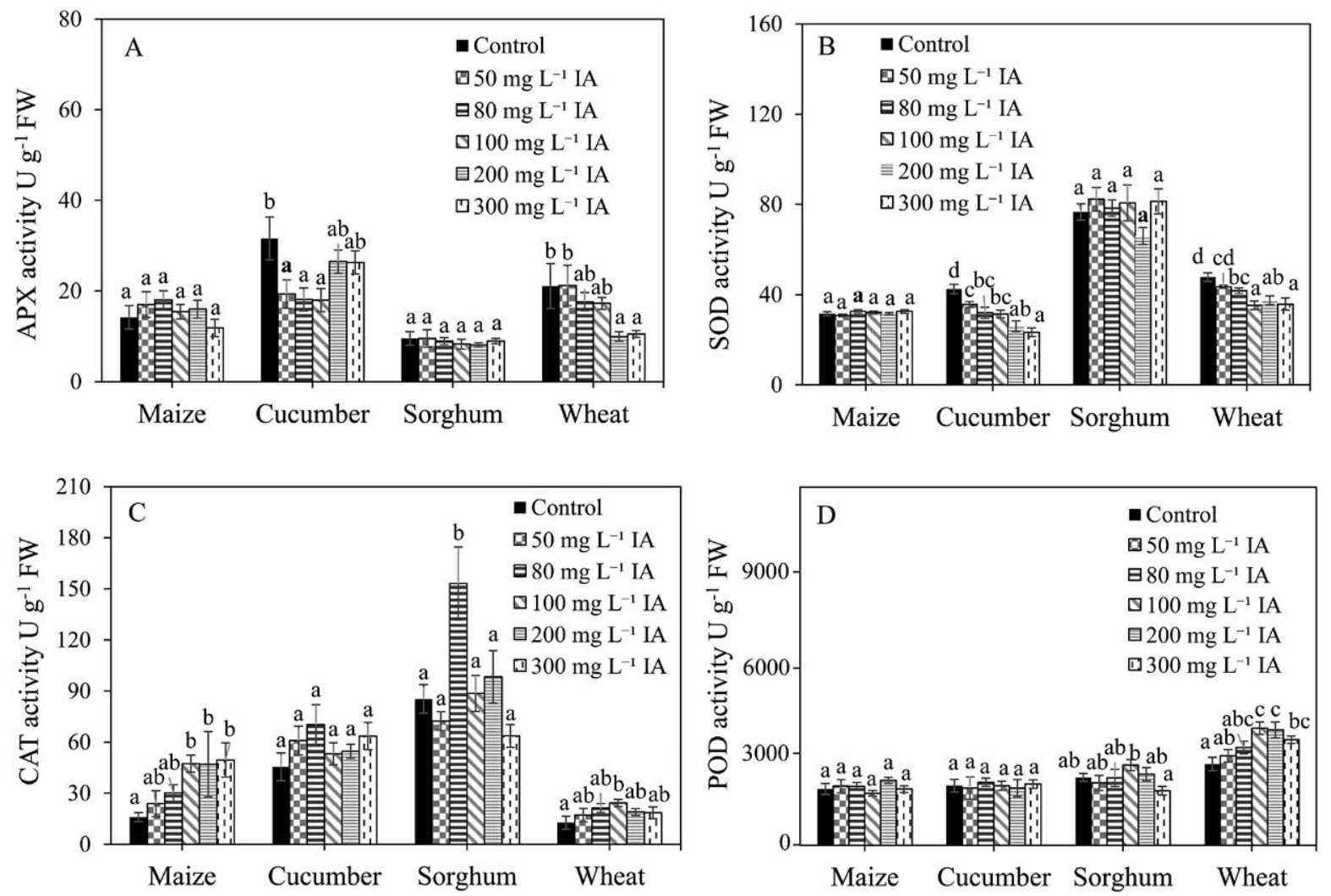

Note. Different letters denote statistically significant differences at $p \leq 0.05$.

Figure 4. Response of ascorbate peroxidase (APX) (A), superoxide dismutase (SOD) (B), catalase (CAT) (C) and peroxidase (POD) (D) activities of investigated crops to itaconic acid (IA) treatment 
similar to salicylic acid, can trigger antioxidant defence response through affecting antioxidant enzymes (Jini, Joseph, 2017). In addition, among the investigated crops, cucumber might be mostly influenced in SOD activity. In general, the scavenging enzymes in early-maturing plants show lower activities than those in normal growth plants. The decline of SOD activity in cucumber and wheat indicated that IA treatment hindered the formation of free radicals. In our opinion, this is the reason that IA may facilitate the maturation of cucumber and wheat.

Catalase (CAT) activity. CAT participates in active oxygen metabolism, and its main function is removal of $\mathrm{H}_{2} \mathrm{O}$ inside cells (Weston, 2000). This is a striking antioxidant defence mechanism, as excessive free radicals give rise to peroxidated damage to cell membrane. Three enzymes CAT, SOD and POD constitute an active oxygen defence system, and the CAT activity reflects plant response to environments. In the present study, the CAT activity in all treatments was enhanced at first but declined later with the increase of IA concentration (Figure 4C). These results indicated that low concentration $\left(100 \mathrm{mg} \mathrm{L}^{-1}\right)$ of IA markedly improved the CAT activity in maize and wheat $(p \leq 0.05)$. Upon $80 \mathrm{mg} \mathrm{L}^{-1}$ IA treatment, sorghum exhibited $79.30 \%$ enhancement in CAT activity relative to the control. The increased CAT activity might be attributed to the steady ROS contents in IA-treated crops, which in turn improved the growth of crops. However, no significant difference in CAT activity was observed in cucumber.

Peroxidase (POD) activity. POD is a highactivity enzyme, which oxidizes substrates using $\mathrm{H}_{2} \mathrm{O}_{2}$ as an electron acceptor. POD has been identified in a panel of crops and is associated with respiration, photosynthesis and auxin oxidation (Diethelm et al., 1990). POD activity varies during the growth and development of crops. In most cases, the aged tissues exhibit higher POD activity relative to the young tissues (Cipollini, Redman, 1999), and high POD activity indicates early maturing of crops, as POD converts some carbohydrates into lignin and thereby contributes to lignification. Figure 4D shows the POD activity of crop seedlings. Although POD exhibited stable and high activity in maize, cucumber and sorghum, no significant difference was observed in the POD activity among IA-treated seedlings. Upon treatment by 100, 200 and $300 \mathrm{mg} \mathrm{L}^{-1} \mathrm{IA}$, wheat showed significant change of POD activity. For sorghum, $100 \mathrm{mg} \mathrm{L}^{-1}$ IA treatment resulted in $18.18 \%$ increase in POD activity.

Malondialdehyde (MDA) content. It has been shown that biosynthesis of MDA in plant tissues is usually triggered by oxidative damage and the imbalance of membrane conductivity (Del Rio et al., 2005). In the present study, IA improved crop growth by reducing MDA (Figure 5). Treatment by 100, 200 and $300 \mathrm{mg} \mathrm{L}^{-1}$ IA markedly reduced the MDA accumulation in maize, cucumber and wheat. In conclusion, IA reduces MDA formation and thus alleviates the oxidative stress on crops.

IA is a biomass-derived chemical and matches sustainable development (Isikgor, Becer, 2015; Teleky, Vodnar, 2019). As a potential fertilizer, IA demonstrates growth-promoting activity (Chien et al., 2014; Peng et al., 2015). Consistent with previous results, in the present study IA improved the growth of four investigated crops. On the other hand, IA exerted different impacts on crops. For instance, $200 \mathrm{mg} \mathrm{L}^{-1}$ IA benefited the growth of maize, cucumber and wheat, as it significantly enhanced leaf area, the CAT activity of maize, but reduced the MDA content. By contrast, high concentration $\left(300 \mathrm{mg} \mathrm{L}^{-1}\right)$ of

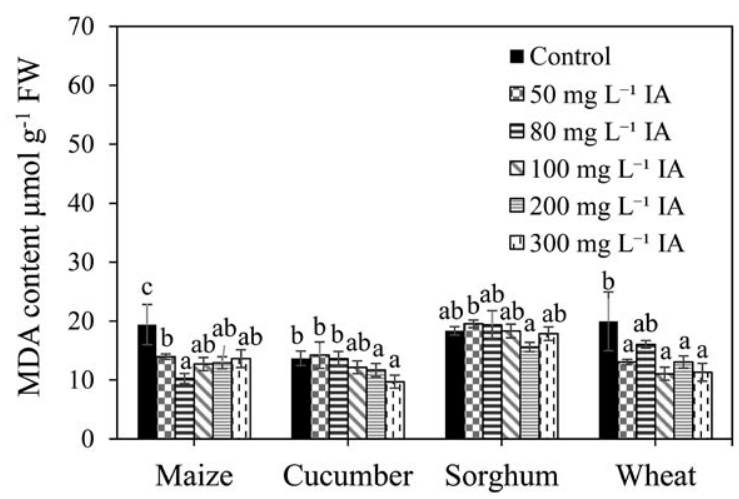

Note. Different letters denote statistically significant differences at $p \leq 0.05$.

Figure 5. Response of malondialdehyde (MDA) content in investigated crops to itaconic acid (IA) treatment

IA retarded the growth of leaves but increased the stem to leaf ratio. In addition, $200 \mathrm{mg} \mathrm{L}^{-1}$ IA led to a $40 \%$ increase in the leaf area, root biomass and total biomass of fresh cucumber seedlings, which is consistent with previous study using ester of IA to treat maize (Todorov et al., 1992). For cucumber, IA led to a decrease in the contents of SOD and MDA. The enlarged leaf area of maize and cucumber was probably ascribed to photosynthesis and gas-exchange (Sun et al., 2015; Kumarathunge et al., 2020). As for the small-leaved sorghum and wheat at four-leaf stage, $80 \mathrm{mg} \mathrm{L}^{-1}$ IA caused an increase in the root and total biomass as well as CAT activity. However, for wheat, IA treatment significantly reduced the stem to leaf and root to shoot ratios indicating that IA promotes leave growth. Furthermore, $200 \mathrm{mg} \mathrm{L}^{-1}$ IA reduced the MDA content and the activities of APX and SOD, but significantly increased the POD activity of wheat. Overall, IA exerts different influences on crops.

\section{Conclusions}

Itaconic acid (IA) benefits crop growth and alleviates oxidative stress.

1. The underlying mechanisms may involve improvement of biomass, leaf area, the activities of catalase (CAT) and peroxidase (POD), but inhibition against malondialdehyde (MDA), ascorbate peroxidase (APX) and superoxide dismutase (SOD).

2. IA exerts different physiological and antioxidant influences on crops.

3. The cucumber and wheat physiological attributes were more influenced by IA than those of maize and sorghum. The reason may be that when cucumber and wheat present well-developed leaves, maize and sorghum are just starting to grow.

4. Through affecting enzyme activity, IA alleviates oxidative stress and benefits crop growth.

Collectively, IA facilitates crop growth by modulating the physiological metabolisms of crops.

\section{Acknowledgments}

This work was financially supported by Key Research and Development Program of Hebei Province (19226509D, 20322501D), National High Technology Research and Development Program (863 Program) (2015AA021003), National Key Research and Development Program of China (2017YFD0201105), 
and Innovation Capability Enhancement Program for Universities Governed by Beijing Municipal Commission of Education (PXM2015 014209 000010).

Received 06062020

Accepted 19012021

\section{References}

Adeleke R., Nwangburuka C., Oboirien B. 2017. Origins, roles and fate of organic acids in soils: a review. South African Journal of Botanv. 108: 393-406.

https://doi.org/10.1016/j.sajb.2016.09.002

Amako K., Chen G.-X., Asada K. 1994. Separate assays specific for ascorbate peroxidase and guaiacol peroxidase and for the chloroplastic and cytosolic isozymes of ascorbate peroxidase in plants. Plant and Cell Physiology, 35 (3): 497-504. https://doi.org/10.1093/oxfordjournals.pcp.a078621

Arnon D. I. 1949. Copper enzymes in isolated chloroplasts. Polyphenoxidase in Beta vulgaris. Plant Physiology, 24 (1): 1-15. https://doi.org/10.1104/pp.24.1.1

Beauchamp C., Fridovich I. 1971. Superoxide dismutase: improved assays and an assay applicable to acrylamide gels. Analytical Biochemistry, 44 (1): 276-287. https://doi.org/10.1016/0003-2697(71)90370-8

Beers R. F. Jr., Sizer I. W. 1952. A spectrophotometric method for measuring the breakdown of hydrogen peroxide by catalase. Journal of Biological Chemistry. 195 (1): 133140. https://doi.org/10.1016/S0021-9258(19)50881-X

Beyer W. F. Jr., Fridovich I. 1987. Assaying for superoxide dismutase activity: some large consequences of minor changes in conditions. Analytical Biochemistry. 161 (2): 559-566. https://doi.org/10.1016/0003-2697(87)90489-1

Chien S. H., Edmeades D., McBride R., Sahrawat K. L. 2014. Review of maleic-itaconic acid copolymer purported as urease inhibitor and phosphorus enhancer in soils. Agronomy Journal. 106 (2): 423-430. https://doi.org/10.2134/agronj2013.0214

Cipollini D. F., Redman A. M. 1999. Age-dependent effects of jasmonic acid treatment and wind exposure on foliar oxidase activity and insect resistance in tomato. Journal of Chemical Ecology, 25 (2): 271-281 https://doi.org/10.1023/A:1020842712349

Cordes T., Michelucci A., Hiller K. 2015. Itaconic acid: the surprising role of an industrial compound as a mammalian antimicrobial metabolite. Annual Review of Nutrition, 35: 451-473.

https://doi.org/10.1146/annurev-nutr-071714-034243

Del Rio D., Stewart A. J., Pellegrini N. 2005. A review of recent studies on malondialdehyde as toxic molecule and biological marker of oxidative stress. Nutrition Metabolism and Cardiovascular Diseases. 15 (4): 316-328. https://doi.org/10.1016/j.numecd.2005.05.003

Diethelm R., Miller M. G., Shibles R., Stewart C. R. 1990. Effect of salicylhydroxamic acid on respiration, photosynthesis, and peroxidase activity in various plant tissues. Plant and Cell Physiology, 31 (2): 179-185. https://doi.org/10.1093/oxfordjournals.pcp.a077890

El-Hamahmy M. A. M., El-Sayed A. I., Odero D. C. 2017. Physiological effects of hot water dipping, chitosan coating and gibberellic acid on shelf-life and quality assurance of sugar snap peas (Pisum sativum L. var. macrocarpon). Food Packaging and Shelf Life, 11: 58-66. https://doi.org/10.1016/j.fpsl.2016.12.002

Forrestal P. J., Harty M., Carolan R., Lanigan G. J., Watson C. J., Laughlin R. J., McNeill G., Chambers B. J., Richards K. G., Nicholson F. 2016. Ammonia emissions from urea, stabilized urea and calcium ammonium nitrate: insights into loss abatement in temperate grassland. Soil Use and Management. 32 (S1): 92-100.

https://doi.org/10.1111/sum.12232

Goldblith S. A., Proctor B. E. 1950. Photometric determination of catalase activity. Journal of Biological Chemistry. 187 (2): 705-709. https://doi.org/10.1016/S0021-9258(18)56216-5
González A., del Mar Gil-Diaz M., del Carmen Lobo M. 2017. Metal tolerance in barley and wheat cultivars: physiological screening methods and application in phytoremediation. Journal of Soils and Sediments, 17 (5): 1403-1412. https://doi.org/10.1007/s11368-016-1387-4

Hillier S., Charnetzky W. T. 1981. Glyoxylate bypass enzymes in Yersinia species and multiple forms of isocitrate lyase in Yersinia nestis. Journal of Bacteriologv. 145 (1): 452-458. https://doi.org/10.1128/JB.145.1.452-458.1981

Huang C.-J., Wei G., Jie Y.-C., Xu J.-J., Zhao S.-Y., Wang L.-C., Anjum S. A. 2015. Responses of gas exchange, chlorophyll synthesis and ROS-scavenging systems to salinity stress in two ramie (Boehmeria nivea L.) cultivars. Photosynthetica, 53 (3): $455-463$ https://doi.org/10.1007/s11099-015-0127-0

Isikgor F. H., Becer C. R. 2015. Lignocellulosic biomass: a sustainable platform for the production of bio-based chemicals and polymers. Polymer Chemistry, 25 (6): 4497 4559. https://doi.org/10.1039/C5PY00263J

Jini D., Joseph B. 2017. Physiological mechanism of salicylic acid for alleviation of salt stress in rice. Rice Science, 24 (2): 97-108. https://doi.org/10.1016/j.rsci.2016.07.007

Kumarathunge D. P., Drake J. E., Tjoelker M. G., López R., Pfautsch S., Vårhammar A., Medlyn B. E. 2020. The temperature optima for tree seedling photosynthesis and growth depend on water innuts. Global Change Biology, 26 (4): 2544-2560. https://doi.org/10.1111/gcb.14975

Magalhaes A. I., de Carvalho J. C., Medina J. D. C., Soccol C. R. 2016. Downstream process development in biotechnological itaconic acid manufacturing. Applied Microbiology and Biotechnology, 101 (1): 1-12. https://doi.org/10.1007/s00253-016-7972-z

Marri L., Thieulin-Pardo G., Lebrun R., Puppo R., Zaffagnini M., Trost P., Gontero B., Sparla F. 2014. CP12-mediated protection of Calvin-Benson cycle enzymes from oxidative stress. Biochimie. 97: 228-237. https://doi.org/10.1016/j.biochi.2013.10.018

Meiser J., Kraemer L., Jaeger C., Madry H., Link A., Lepper P. M., Hiller K., Schneider J. G. 2018. Itaconic acid indicates cellular but not systemic immune system activation. Oncotarget, 9(63): 32098-32107. https://doi.org/10.18632/oncotarget.25956

Mittler R. 2002. Oxidative stress, antioxidants and stress tolerance. Trends in Plant Science, 7 (9): 405-410. https://doi.org/10.1016/S1360-1385(02)02312-9

Müller F., Torger B., Allertz P. J., Jähnichen K., Keßler S., Müller M., Simon F., Salchert K., Mäurer H., Pospiech D. 2018. Multifunctional crosslinkable itaconic acid copolymers for enzyme immobilization. European Polymer Journal, 102: 47-55. https://doi.org/10.1016/j.eurpolymj.2018.03.014

Nakano Y., Asada K. 1981. Hydrogen peroxide is scavenged by ascorbate-specific peroxidase in spinach chloroplasts. Plant and Cell Physiologv. 22 (5): 867-880 https://doi.org/10.1093/oxfordjournals.pcp.a076232

Patel T. R., McFadden B. A. 1978. Caenorhabditis elegans and Ascaris suum: inhibition of isocitrate lyase by itaconate. Experimental Parasitology, 44 (2): 262-268. https://doi.org/10.1016/0014-4894(78)90107-8

Peng X., Maharjan B., Yu C., Su A., Jin V., Ferguson R. B. 2015. A laboratory evaluation of ammonia volatilization and nitrate leaching following nitrogen fertilizer application on a coarse-textured soil. Journal of Agronomy, 107 (3): 871-879. https://doi.org/10.2134/agronj14.0537

Qi P., Chen H.-L, Nguyen H. T. H., Lin C.-C, Miller S. A. 2016. Synthesis of biorenewable and water-degradable polylactam esters from itaconic acid. Green Chemistry. 18 (15): 4170-4175. https://doi.org/10.1039/C6GC01081D

Racchi M. L. 2013. Antioxidant defenses in plants with attention to Prunus and Citrus spp. Antioxidants, 2 (4): 340-369. https://doi.org/10.3390/antiox2040340

Ramos J. L., Udaondo Z., Fernández B., Molina C., Daddaoua A., Segura A., Duque E. 2016. First- and second-generation biochemicals from sugars: biosynthesis of itaconic acid. Microbial Biotechnology, 9 (1): 8-10. https://doi.org/10.1111/1751-7915.12333 
Robert T., Friebel S. 2016. Itaconic acid - a versatile building block for renewable polyesters with enhanced functionality. Green Chemistrv. 18 (10): 2922-2934.

https://doi.org/10.1039/C6GC00605A

Ryan D. G., Murphy M. P., Frezza C., Prag H. A., Chouchani E. T., O’Neill L. A., Mills E. L. 2019. Coupling Krebs cycle metabolites to signalling in immunity and cancer. Nature Metabolism. 1 (1): 16-33. https://doi.org/10.1038/s42255-018-0014-7

Sanders J. L. 2010. Gypsum fertilizer products with polymer adjuvants. United States Patent. https://patentimages.storage. googleapis.com/44/4c/d9/ef5efbf6a60718/US7686863.pdf

Schmedes A., Hølmer G. 1989. A new thiobarbituric acid (TBA) method for determining free malondialdehyde (MDA) and hydroperoxides selectively as a measure of lipid peroxidation. Journal of the American Oil Chemists Societv. 66: 813-817. https://doi.org/10.1007/BF02653674

Shahabivand S., Maivan H. Z., Mahmoudi E., Soltani B. M., Aliloo A. A. 2016. Antioxidant activity and gene expression associated with cadmium toxicity in wheat affected by mycorrhizal fungus. Zemdirbyste-Agriculture, 103 (1): 53-60. https://doi.org/10.13080/z-a.2016.103.007

Sun S., Li M., Zuo J., Jiang W., Liu D. 2015. Cadmium effects on mineral accumulation, antioxidant defence system and gas exchange in cucumber. Zemdirbvste-Agriculture. 102 (2): 193-200. https://doi.org/10.13080/z-a.2015.102.025

Takić Miladinov D., Tomić S., Stojanović S., Najdanović J., Filipović J., Trajanović M., Najman S. 2016. Synthesis, swelling properties and evaluation of genotoxicity of hydrogels based on (meth)acrylates and itaconic acid. Materials Research, 19 (5): 1070-1079.

https://doi.org/10.1590/1980-5373-MR-2016-0222
Teleky B.-E., Vodnar D. C. 2019. Biomass-derived production of itaconic acid as a building block in specialty polymers. Polvmers (Basel). 11 (6): 1035. https://doi.org/10.3390/polym11061035

Todorov D., Alexieva V., Karanov E., Velichkov D., Velikova V. 1992. Effect of certain dicarboxylic acid monoesters on growth, chlorophyll content, chlorophyllase and peroxidase activities, and gas-exchange of young maize plants. Journal of Plant Growth Regulation, 11 (4): 233. https://doi.org/10.1007/BF02115483

Urbano-Juan M. M., Socías-Viciana M. M., Ureña-Amate M. D. 2019. Evaluation of nitrate controlled release systems based on (acrylamide-co-itaconic acid) hydrogels. Reactive and Functional Polvmers. 141: 82-90. https://doi.org/10.1016/j.reactfunctpolym.2019.05.007

Werpy T., Petersen G. (eds). 2004. Top value added chemicals from biomass. U.S. Department of Energy by the National Renewable Energy Laboratory, 68 p.

Weston R. J. 2000. The contribution of catalase and other natural products to the antibacterial activity of honey: a review. Food Chemistrv. 71 (2): 235-239.

https://doi.org/10.1016/S0308-8146(00)00162-X

Zhao M., Lu X., Zong H., Li J., Zhuge B. 2018. Itaconic acid production in microorganisms. Biotechnology Letters, 40(3): 455-464. https://doi.org/10.1007/s10529-017-2500-5

Zheng W., Zhong Z.-Y., Wang H.-B., Wang H.-J., Wu D.-M. 2018. Effects of oxalic acid on arsenic uptake and the physiological responses of Hydrilla verticillata exposed to different forms of arsenic. Bulletin of Environmental Contamination and Toxicology, 100 (5): 653-658. https://doi.org/10.1007/s00128-018-2304-x

\title{
Itakono rūgšties įtaka augalų daigų fiziologinẻms savybẻms
}

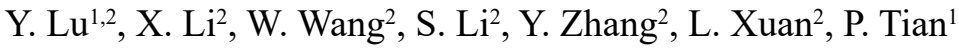 \\ ${ }^{1}$ Pekino chemijos technologijos universitetas, Kinija \\ ${ }^{2}$ Tarimo universitetas, Kinija
}

\section{Santrauka}

Itakono rūgštis yra ekonomiškai svarbi cheminè medžiaga, plačiai naudojama chemijos pramonèje ir žemės ūkyje. Tyrimo metu siekta nustatyti itakono rūgšties įtaką augalų daigams. Keturių rūšių augalai - kukurūzai, agurkai, sorgai ir kviečiai - auginti hidroponikoje vermikulite, papildytame standartiniu Hoaglando maisto medžiagų tirpalu ir viena doze serijiniu būdu praskiestos itakono rūgšties. Nustatyta daigų biomasé, fermentų antioksidacinis aktyvumas ir chlorofilo bei malondialdehido kiekis. Tyrimo rezultatai parodè, kad maža itakono rūgšties koncentracija ( $\left.\leq 200 \mathrm{mg} \mathrm{L}^{-1}\right)$ skatino augalų augimą ir švelnino oksidacinị stresą, padidino biomasę, lapų plotą, chlorofilo kiekį, katalazès ir peroksidazės aktyvumą, sumažino malondialdehido susidarymą ir askorbato peroksidazès bei superoksido dismutazės aktyvumą. Itakono rūgštis turèjo nevienodą fiziologinę ir antioksidacinę ịtaką augalams. Fiziologinis poveikis augalams mažėjo tokia seka: agurkai $>$ kviečiai $>$ kukurūzai $>$ sorgai. Itakono rūgštis augalų augimą skatino veikdama biocheminius junginius, pavyzdžiui, antioksidacinius fermentai ir chlorofilą.

Tyrimo rezultatai rodo, kad ateityje itakono rūgštis galès būti naudojama kaip trąša.

Reikšminiai žodžiai: antioksidaciniai fermentai, augalų daigai, fiziologinis poveikis, itakono rūgštis. 